\title{
A REQUIREMENT ENGINEERING IN REPORTING AND COUNSELING- BASED ASSISTANCE APPLICATION FOR VICTIMS OF VIOLENCE AGAINST WOMEN
}

\author{
Dwi Hosanna Bangkalang ${ }^{1 *}$, Nina Setiyawati ${ }^{2}$, Radius Tanone ${ }^{3}$, Hanna P. Chernovita ${ }^{4}$, Yuliana T. B. Tacoh ${ }^{5}$ \\ Faculty of Information Technology \\ Universitas Kristen Satya Wacana \\ dwihosanna.bangkalang@uksw.edu $\left.{ }^{1 *}\right)$, nina.setiyawati@uksw.edu², radius.tanone@uksw.edu ${ }^{3}$, \\ hanna.chernovita@uksw.edu ${ }^{4}$,yuliana.tacoh@uksw.edu ${ }^{5}$ \\ (*) Corresponding Author
}

\begin{abstract}
Requirements engineering is the initial phase of the software development life cycle it is a critical aspect of application development since it has a significant impact on the results of the product being created. This article focuses on the engineering requirements of the web-based application development process for reporting and assisting victims of violence against women using the Loucopoulos and Kanakostas Iterative Requirements Engineering Process Model. The application was created to contribute to the solution of the problem of violence against women in Indonesia, where violence against women is an iceberg phenomenon because not all incidents are reported. Furthermore, victims of violence against women require support in receiving emotional support in the form of counseling, which can be done online via chat or video calls. The results of these requirements engineering are alternative solutions, application feature design, database design, system modeling using UML, and application architecture design. The validation of requirements engineering was carried out using a low fidelity prototype.
\end{abstract}

Keywords: requirement engineering, violence against women, counseling, reporting

\begin{abstract}
Abstrak
Rekayasa kebutuhan adalah fase awal dari siklus hidup pengembangan perangkat lunak yang merupakan bagian krusial dalam pembangunan aplikasi karena memiliki dampak yang sangat besar pada hasil yang akan diperoleh dari produk yang dibangun. Artikel ini berfokus pada rekayasa kebutuhan proses pembangunan aplikasi pelaporan dan pendampingan korban kekerasan pada perempuan berbasis web dengan menggunakan Loucopoulos and Kanakostas Iterative Requirements Engineering Process Model. Adapun pembangunan aplikasi dilakukan untuk menjadi bagian solusi dari permasalahan kekerasan terhadap perempuan yang ada di Indonesia, di mana kekerasan terhdap perempuan merupakan fenomena es karena tidak semua kasus dilaporkan. Selain itu, korban kekerasan terhadap perempuan juga membutuhkan pendampingan untuk mendapatkan dukungan emosional berupa konseling yang dapat dilakukan secara daring baik melalui chatting maupun video call. Hasil dari rekayasa kebutuhan ini adalah alternatif solusi, rancangan fitur aplikasi, rancangan basis data, pemodelan sistem menggunakan UML, dan rancangan arsitektur aplikasi. Adapun validasi dari rekayasa kebutuhan dilakukan menggunakan prototype low fidelity.
\end{abstract}

Kata kunci: rekayasa kebutuhan, kekerasan terhadap perempuan, konseling, pelaporan

\section{INTRODUCTION}

Requirements engineering is the initial phase of the software development life cycle where requirements such as user requirements and system requirements are collected, understood, and analyzed for software product development (Udousoro, 2020). This is a critical stage in the development of an application (Mead \& Stehney, 2005) because it has a significant impact on the results of the product being developed. The requirements engineering phase involves every stakeholder including the user where in general will produce a definition of the required application features and capabilities.

This article focuses on the engineering needs of the web-based application development process for reporting and assisting victims of violence against women. The application was created as part of a solution to Indonesia's problem of domestic violence against women. Violence against women in Indonesia is an iceberg 
phenomenon because not all cases are reported (Susiana, 2020). As a result, there is a discrepancy between the number of cases of violence against women reported and the actual number of cases (Trihastuti \& Nuqul, 2020). This application is part of an effort to raise awareness about the importance of reporting cases of violence against women in the community. In addition, it is also to accommodate and provide progress on reporting violence against women, so that it may be dealt with as efficiently as possible.

Violence against women not only has a physical consequence but also a mental impact on the victim. The negative impacts experienced by victims of women's violence are depression, sadness, feeling dirty, fear, low self-confidence, difficulty in controlling emotions, fear of marriage, depression, depression, and disgust with himself. In addition, it also causes the effects of sadness, resentment, anger, shame, and feeling insignificant, which also has an impact on the victim's physical appearance, namely hair loss and a decline in physical condition since it corresponds to a fall in appetite (Artaria, 2012; Trihastuti \& Nuqul, 2020). Therefore, it is necessary to assist victims of violence against women for emotional support. Victims can receive assistance in the form of counseling, where this is included in individual treatment interventions (Fisher, 2004).

Online counseling has a lot of potential these days since it can help somebody who has an issue but is too embarrassed to address it in front of other people (Ardi et al., 2017), particularly for Indonesians who still hold a negative stigma towards counseling sessions. Furthermore, online counseling is recommended for individuals who require counseling sessions but are unable to do so due to transportation issues or a lack of time (Snyder et al., 2014; Stevens et al., 2014).

The purpose of this study is to design an application to report and give first-hand psychological assistance with a counseling approach for victims of violence against women. It is hoped that this application would assist and encourage victims to report incidents of violence. This is one of the initiatives aimed at increasing the reporting of incidences of violence against women to create community awareness about the issue. In addition, with this application, it is hoped that victims of violence can receive counseling-based psychological assistance.

\section{RESEARCH METHODS}

Requirements engineering has an essential role in the effectiveness of software development (Febiana, 2015). In the requirements engineering process, it is necessary to define the quality and important requirements needed for software development. The requirements engineering process model used in this study is the Loucopoulos and Kanakostas Iterative Requirements Engineering Process Model as shown in Figure 1 (Ekanem et al., 2019; Martin et al., 2002).

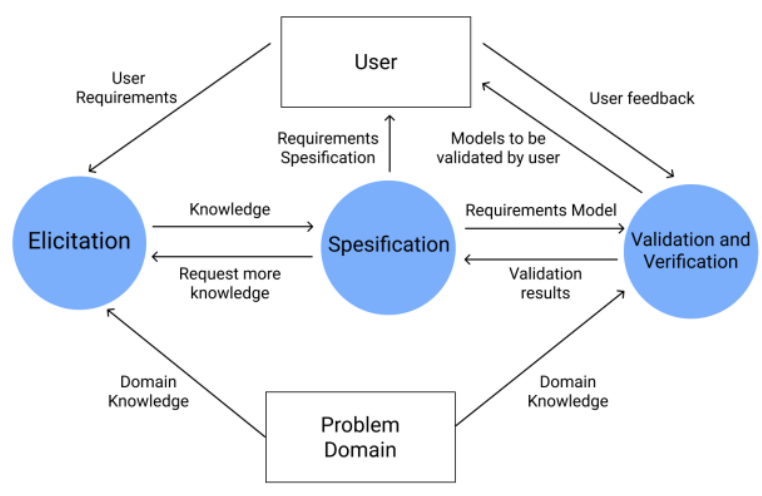

Figure 1. Loucopoulos and Kanakostas Iterative Requirements Engineering Process Model

\section{Elicitation}

This stage is also known as the needs gathering stage because the main activity carried out is needs gathering from stakeholders (Ramadan \& Megahed, 2016; Udousoro, 2020). This activity results in the identification of a problem, the formulation of system constraints, and system constraints.

2. Specification

At this stage, an examination of the consistency, completeness, and feasibility of the requirements was carried out through a process of communication, prioritization, and negotiation. At this stage, all of the requirements were written down in a formal document. The main purpose of the documentation is communication between developers and stakeholders (Ramadan \& Megahed, 2016). Therefore, the documents produced by the requirements must be clear, consistent, concise, and feasible (Paetsch et al., 2003; Saito et al., 2017).

3. Validation and Verification

This stage was carried out to confirm and ensure that the user's requirements and the specification of requirements are complete and correct. One of the methods used is prototyping.

\section{RESULTS AND DISCUSSION}

In the requirements elicitation stage, problem identification was carried out by interviewing and also studying literature on the data of violence against women. Some of the problems encountered were; 1 ) that many women did not report the violence they were subjected to; 2 ) the 
need for media that enabling reporting to rapidly request assistance; 3) many women were hesitant to seek help because they were concerned that their personal information will be known or revealed; 4) many Indonesian women have multiple roles, namely household roles, and breadwinners, resulting in insufficient time to visit counselors; 5) the stigma attached to victims of violence against women in Indonesian society is still negative.

From these problems, exploration and formulation of alternative solutions were carried out as shown in Table 1.

Table 1. Alternative Exploration of Solutions

\begin{tabular}{llll}
\hline No. & \multicolumn{1}{c}{ Aim } & \multicolumn{1}{c}{ Needs } & \multicolumn{1}{c}{ Solution } \\
\hline 1 & $\begin{array}{l}\text { Increase awareness and willingness of } \\
\text { victims and the community to report } \\
\text { violence against women }\end{array}$ & $\begin{array}{l}\text { A media to report the occurrence } \\
\text { of violence }\end{array}$ & $\begin{array}{l}\text { Develop a web-based application that } \\
\text { allows victims and the public to report } \\
\text { violent acts. }\end{array}$ \\
& $\begin{array}{l}\text { Assist victims of violence in a flexible } \\
\text { and credible manner }\end{array}$ & $\begin{array}{l}\text { A counseling system that ensures } \\
\text { the confidentiality of the } \\
\text { counselee's data }\end{array}$ & $\begin{array}{l}\text { Develop a counseling-based assistance } \\
\text { system that can be accessed from } \\
\text { anywhere and the counselee has the right } \\
\text { of independence to hide personal data } \\
\text { from the counselor }\end{array}$ \\
& Helping women get help with & A media that enables women to \\
& seek assistance or report violence \\
in real-time. & $\begin{array}{l}\text { Develop a mobile-friendly reporting } \\
\text { application that can be accessed instantly. }\end{array}$
\end{tabular}

The solution defined in Table 1 is the foundation for determining the application's functional needs. The functional requirements of the application are shown in Table 2.

Table 2. Definition of Application Functional Requirements

\begin{tabular}{|c|c|c|}
\hline No. & Needs & Feature \\
\hline 1 & $\begin{array}{l}\text { Victims or the general public can report incidents of } \\
\text { violence }\end{array}$ & Reporting incidents of violence \\
\hline 2 & $\begin{array}{l}\text { The status of the reported occurrence can be tracked } \\
\text { by the reporter }\end{array}$ & Report dashboard to the complainant/reporter \\
\hline 3 & $\begin{array}{l}\text { The reporter will be able to provide the specific } \\
\text { location of the incident }\end{array}$ & Retrieve current location using the in-app map \\
\hline 4 & $\begin{array}{l}\text { Reporters can download a list of reports that have } \\
\text { been reported }\end{array}$ & Download reports in a pdf or excels format \\
\hline 5 & $\begin{array}{l}\text { Victims and the general public can easily request } \\
\text { immediate assistance. }\end{array}$ & $\begin{array}{l}\text { The SOS button can directly send the location of the reporter without } \\
\text { logging in and can be utilized as a shortcut on the reporter's mobile } \\
\text { device for quick access when needed }\end{array}$ \\
\hline 6 & Victims can get online counseling assistance & Online counseling \\
\hline 7 & $\begin{array}{l}\text { Victims can independently choose a counselor and } \\
\text { counseling time }\end{array}$ & \\
\hline 8 & $\begin{array}{l}\text { Victims can choose to show their data or not to the } \\
\text { counselor }\end{array}$ & The option of hiding the victim's data \\
\hline 9 & $\begin{array}{l}\text { Referral of the victim to another counselor must be } \\
\text { known and through the victim's consent }\end{array}$ & Referral counselee \\
\hline 10 & $\begin{array}{l}\text { Discussion of the victim's problem by the counselor } \\
\text { with other counselors must be known and through the } \\
\text { victim's consent }\end{array}$ & Case conference counselee \\
\hline 11 & Victims can get counseling sessions via written chat & Counseling room \\
\hline 12 & Victims can get counseling sessions via video call & Video conferencing that can be made by a counselor \\
\hline 13 & $\begin{array}{l}\text { Counselors and victims are kept up to date on the } \\
\text { current application activity. }\end{array}$ & Email notifications \\
\hline 14 & $\begin{array}{l}\text { The public can view the number of reports, counseling, } \\
\text { and requests for immediate assistance in the } \\
\text { application. }\end{array}$ & $\begin{array}{l}\text { Dashboard of the number of reports, counseling, and requests for } \\
\text { quick help that can be seen on the landing page of the application }\end{array}$ \\
\hline
\end{tabular}

At the specification stage, the functional requirements are translated into a system model. Some of the approaches taken in this research are: 1) Unified Modeling Language (UML) which is the standard modeling language (Lange et al., 2006) and has several diagrams to explain applications in the form of behavioral, structural, and supplemental modeling. The diagrams used are use case diagrams and activity diagrams. 2) Database design to describe the relationship between tables used in the application. 3) Application architecture that 
provides an overview of the patterns and techniques used in building applications.

Use case diagram is a form of visual representation of the context of the interaction between actors and the system (Kurniawan, 2018). This diagram is a concept of user needs analysis where each use case states the application functionality that can be used by actors. Use case diagrams also explain the behavior of the application from the user's point of view. The use case diagram of the application is shown in Figure 2.

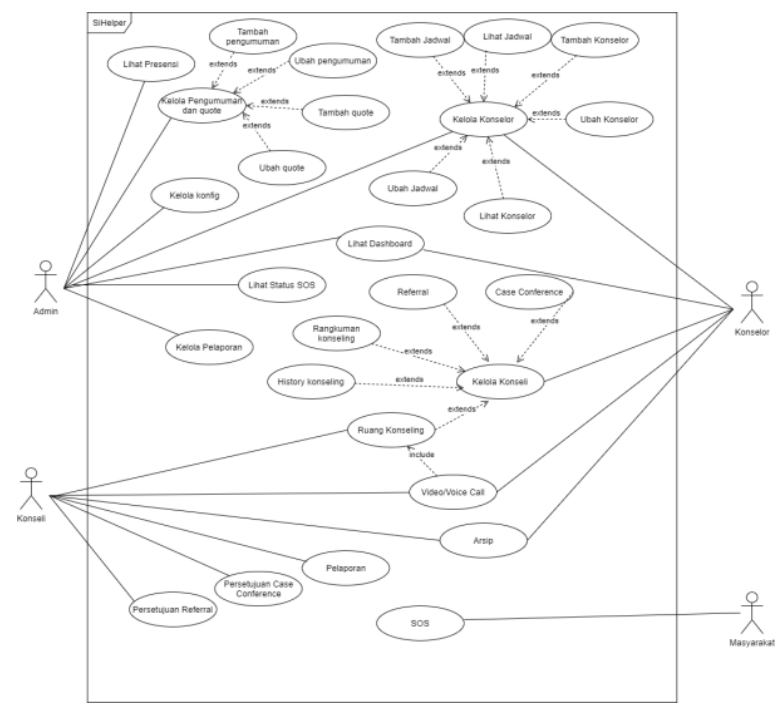

Figure 2. Use Case Diagram Application

Activity diagram is used to model logical behavior such as business processes, workflows, or activities of a system (Bhattacharjeem \& Shyamasundar, 2009; Wati \& Kusumo, 2016). The application activity diagram shown in Figure 3, Figure 4, and Figure 5.

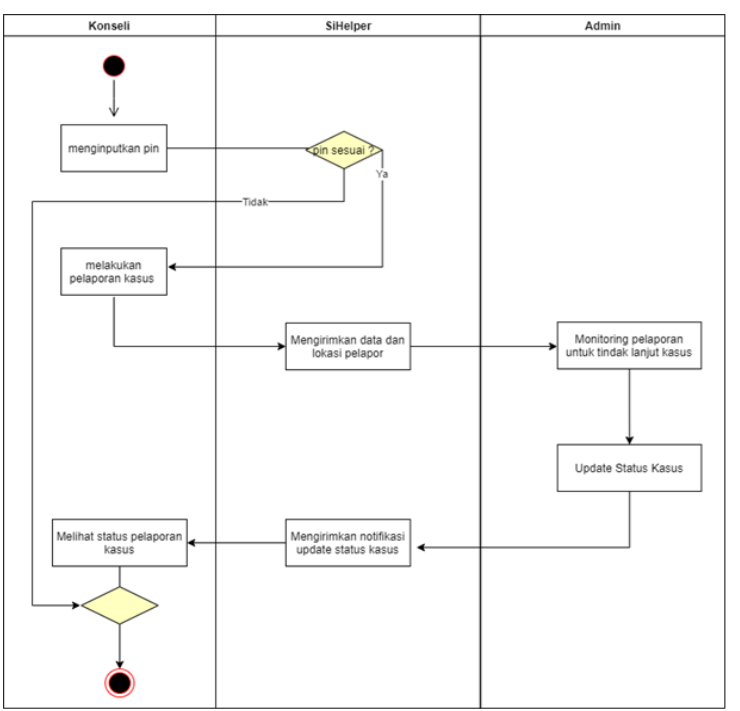

Figure 3. Activity Diagram Reporting
Figure 3 shows the reporting activity in the reporting module where after successfully logging in, the user accesses the reporting menu and fills in data in the fields provided, including retrieving the location of the reporter and the incident of violence using the map on the application. The reporter can track the progress of the completed report in this module.

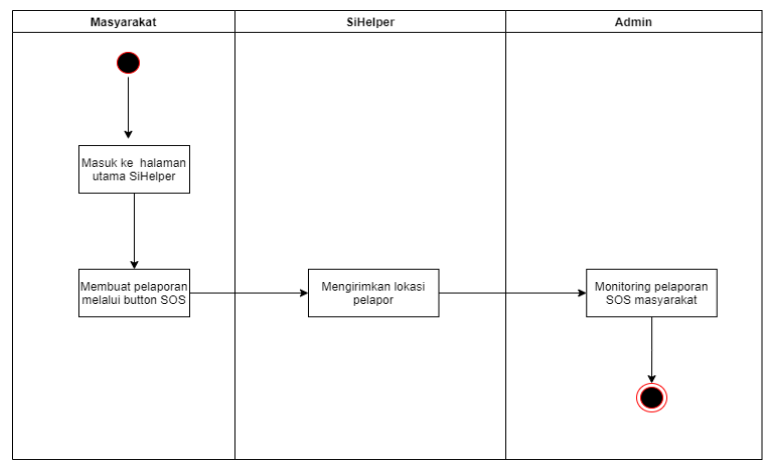

Figure 4. Activity Diagram for Quick Help Request

In the quick help request module, the activity of the reporter, as shown in Figure 4, is to use the SOS button to provide info on violent occurrences with minimal fields, namely name, email, and location of the incident that can be retrieved automatically via a map on the application.

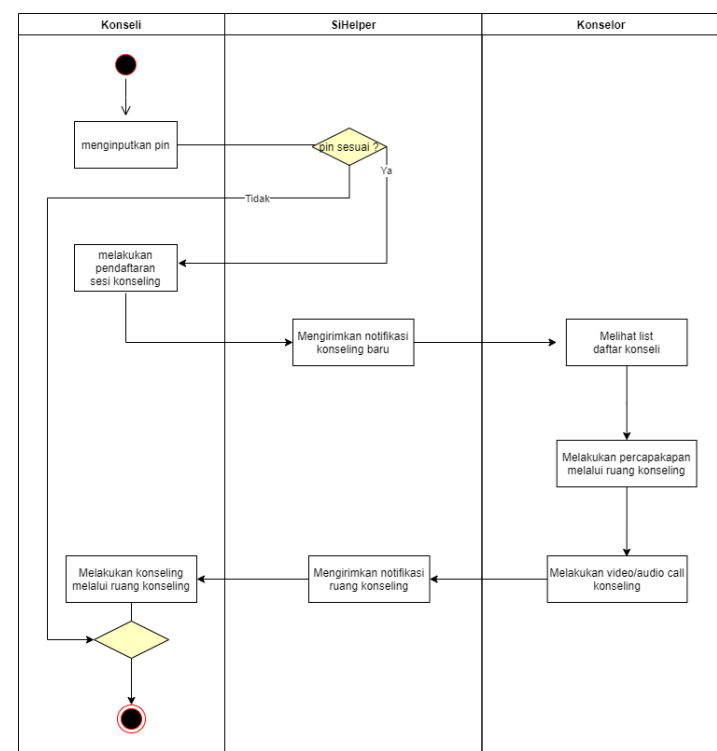

Figure 5. Activity Diagram of Online Counseling

In Figure 5 it can be seen that the actors who are active in the counseling feature are the counselee and the counselor. After successfully logging in, the counselee can register for a counseling session by selecting a counselor and the desired counseling time. When registering for a counseling session, the counselee is asked whether personal information should be displayed to the counselor. After 
successfully registering for a counseling session, the counseling session data is entered into the counselor module, enabling the session schedule at that moment to be marked unavailable and inaccessible to other counselees. Counselors and counselees can initiate counseling either through chat or video calls.

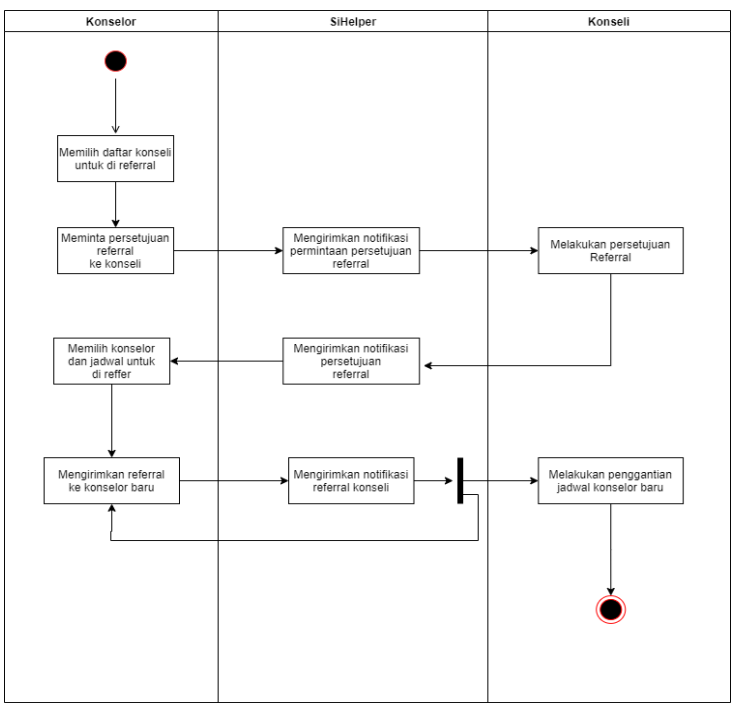

Figure 6. Counseling Referral Activity Diagram
Figure 6 shows the activities of counselors and counselees in the counseling referral process which begins with a request for consent from the counselee to be referred to another counselor. If the counselee agrees to be referred then the counselor will choose another counselor and the available schedule. Another design that is carried out in a database design that describes the details of the relationships between tables and table attributes. The application database design is shown in Figure 7.
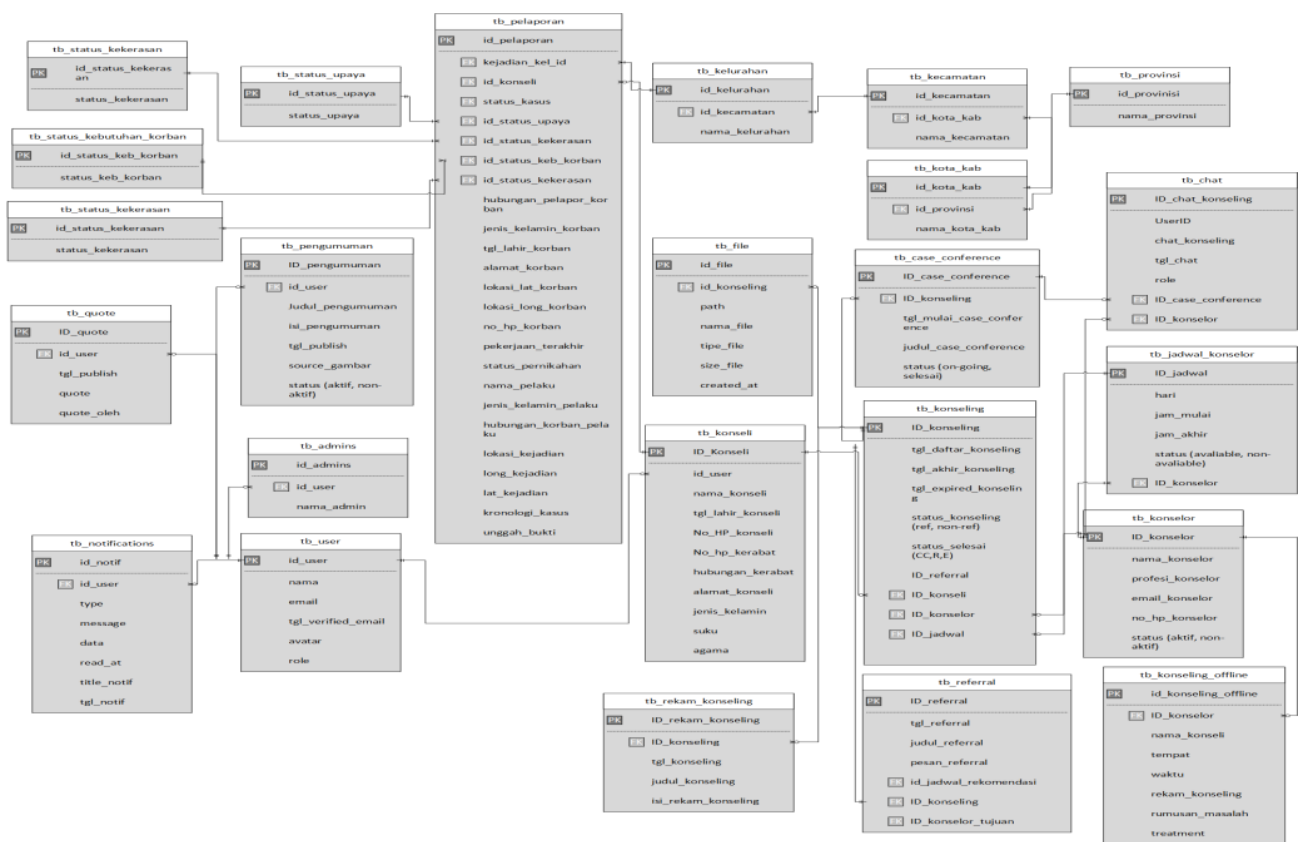

Figure 7. Database Design

The application architecture is created to provide a roadmap and best practices to follow when creating an application, resulting in a well-structured application (RedHat, 2021). The application architecture diagram provides a high-level graphical view of the application architecture, which can provide a clear representation of the parts in the application such as sub-applications, components, databases, services, etc., and their interactions (Giachetti, 2020). The application architecture shown in Figure 8. The application will built using the Laravel framework's Hypertext 
Preprocessor (PHP) programming language. For the video call process, the application is equipped with a video call module that utilizes the WebRTC specification. The quick help request module or SOS is built using Progressive Web Application technology. Main module data communication with the SOS module is done using JSON. To retrieve the user's location, the Google Maps API is used.

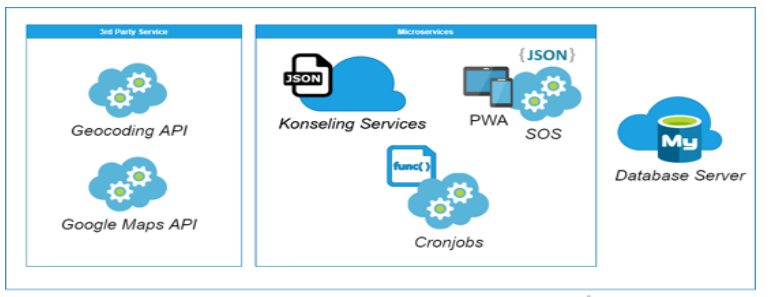

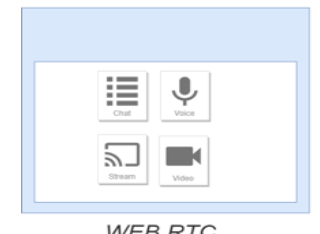

WEB RTC
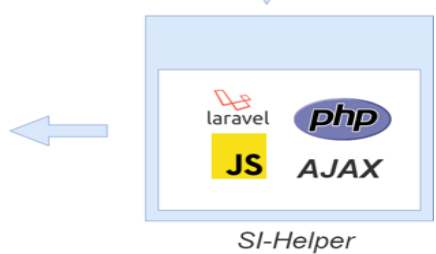

Sl-Helper
Figure 8. Architecture Design Application

The validation stage is carried out using the prototyping method which is a form of solution visualization (Anas et al., 2016) so that stakeholders can ensure that the designed solution is by user needs. The prototype produced at this stage serves to communicate ideas in real terms (Lauff et al., 2018) as well as guide application development efforts. The low fidelity prototype (Lang \& Mjöberg, 2020) of the counselee dashboard and SOS is shown in Figures 9 and 10.

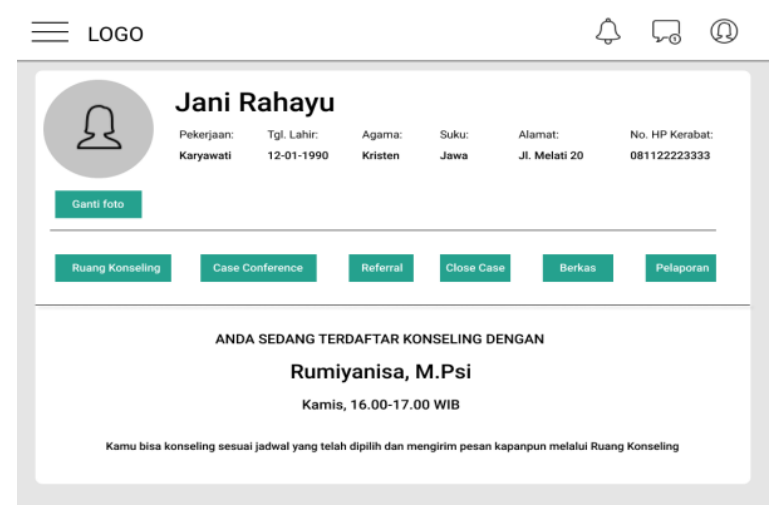

Figure 9. Counselee Dashboard Mockup

On the counselee's dashboard, you can see some information such as the profile and who is being registered in the counseling session by the counselor, and at what time. If a counselee has been registered in a counseling session, then the counselee is counseled in the counseling room, closes the counseling session if it is deemed sufficient, views the files distributed by the counselor, and approves if there is a case conference or referral request. The counselee can also enter the reporting module via the reporting button. In the counselee header, there are activity notifications and chat notifications to find out if there is new information and new chat.

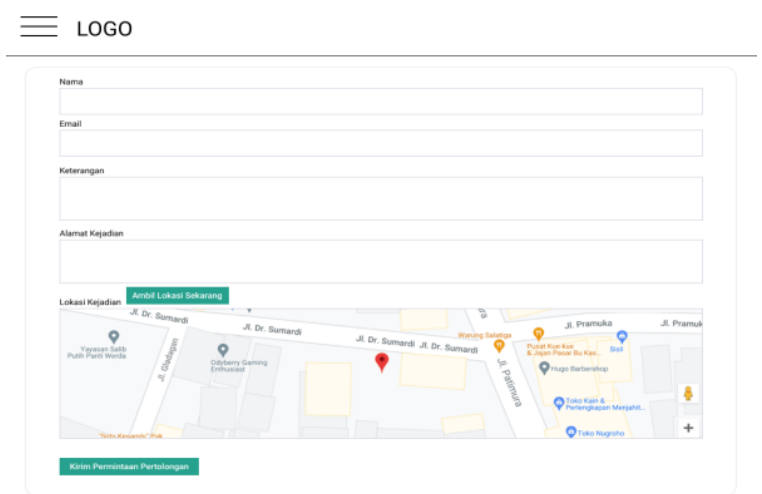

Figure 10. Mockup SOS

On the SOS page, the complainant must fill in the name, email, description, and location of the incident which can be retrieved from the map.

\section{CONCLUSIONS AND SUGGESTIONS}

\section{Conclusion}

The needs engineering conducted reveals the details of the problem as well as the necessity to assist victims of violence against women. Based on the exploration of alternative solutions, a system model generated as a guide for application development.

\section{Suggestion}

System modeling can augmented by some techniques in UML or using other approaches. Requirements validation can also added with other methods.

\section{REFERENCES}

Anas, H., Ilyas, M., Tariq, Q., \& Hummayun, M. (2016). Requirements Validation Techniques: An Empirical Study. International Journal of Computer Applications, 148(14), 5-10. https://doi.org/10.5120/ijca2016910911

Ardi, Z., Putra, M. R. M., \& Ifdil, I. (2017). Ethics And Legal Issues In Online Counseling Services: Counseling Principles Analysis. Jurnal Psikologi Pendidikan Dan Konseling: Jurnal Kajian Psikologi Pendidikan Dan Bimbingan 
Konseling,

$3(2)$,

15.

https://doi.org/10.26858/jpkk.v0i0.3657

Artaria, M. D. (2012). Efek Pelecehan Seksual di Lingkungan Kampus: Studi Preliminer. BioKultur, 1(1), 53-72.

Bhattacharjeem, A. K., \& Shyamasundar, R. K. (2009). Activity diagrams: A formal framework to model business processes and code generation. Journal of object Technology, 8(1), 189-220. https://doi.org/10.5381/jot.2009.8.1.a3

Ekanem, A. J., Valentine, U. I., \& Nwakaego, I. P. (2019). A Participatory Requirement Engineering Process (PREP) Model for Software Development Projects. 6(9), 10789-10796.

Febiana, C. C. (2015). Evaluasi Kematangan Proses Rekayasa Kebutuhan Dengan Mengacu Model Repm ( Requirement Engineering Process Maturity) Dan Cmmi ( Capability Maturity Model Integration) ( Studi Kasus : Lptsi Its ) Evaluate Meturity Level of Requirement Engineering Process .

Fisher, B. S. (2004). Prevention and Intervention: Collaborations, Policies, Programs, and Services. Violence Against Women and Family Violence: Developments in Research, Practice, and Policy, I-4-3-I-4-16.

Giachetti, R. (2020). Enterprise Architecture. Design of Enterprise Systems, 118-135. https://doi.org/10.1201/9781439882894 $-10$

Kurniawan, T. A. (2018). Pemodelan Use Case (UML): Evaluasi Terhadap beberapa Kesalahan dalam Praktik. Jurnal Teknologi Informasi Dan Ilmu Komputer, 5(1), 77. https://doi.org/10.25126/jtiik.20185161 0

Lang, F., \& Mjöberg, A. (2020). Prototyping as a Requirements Engineering Technique.

Lange, C. F. J., Chaudron, M. R. V., \& Muskens, J. (2006). In practice: UML software architecture and design description. IEEE Software, 23(2), 40-46. https://doi.org/10.1109/MS.2006.50

Lauff, C. A., Kotys-Schwartz, D., \& Rentschler, M. E. (2018). What is a prototype? what are the roles of prototypes in companies? Journal of Mechanical Design, Transactions of the ASME, $140(6)$. https://doi.org/10.1115/1.4039340

Martin, S., Aurum, A., Jeffery, R., \& Paech, B. (2002). Requirements Engineering Process Models in Practice. October 2014.

Mead, N. R., \& Stehney, T. (2005). Security quality requirements engineering (SQUARE) methodology. SESS 2005 - Proceedings of the 2005 Workshop on Software Engineering for Secure Systems - Building Trustworthy Applications, November. https://doi.org/10.1145/1083200.108321 4

Paetsch, F., Eberlein, A., \& Maurer, F. (2003). Requirements engineering and agile software development. Proceedings of the Workshop on Enabling Technologies: Infrastructure for Collaborative Enterprises, WETICE, 2003-Janua(December 2014), 308-313.

https://doi.org/10.1109/ENABL.2003.123 1428

Ramadan, N., \& Megahed, S. (2016). Requirements Engineering in Scrum Framework. International Journal of Computer Applications, 149(8), 24-29. https://doi.org/10.5120/ijca2016911530

RedHat. (2021). What is an application architecture? https://www.redhat.com/en/topics/cloud -native-apps/what-is-an-applicationarchitecture

Saito, S., Iimura, Y., Massey, A. K., \& Anton, A. I. (2017). How Much Undocumented Knowledge is there in Agile Software Development?: Case Study on Industrial Project Using Issue Tracking System and Version Control System. Proceedings - 2017 IEEE 25th International Requirements Engineering Conference, RE 2017, 194-203. https://doi.org/10.1109/RE.2017.33

Snyder, M. E., Frail, C. K., Jaynes, H., Pater, K. S., \& Zillich, A. J. (2014). Predictors of medication-related problems among medicaid patients participating in a pharmacist-provided telephonic medication therapy management program. Pharmacotherapy, 34(10), 1022-1032. https://doi.org/10.1002/phar.1462

Stevens, T. B., Richmond, N. L., Pereira, G. F., Shenvi, C. L., \& Platts-Mills, T. F. (2014). Prevalence of nonmedical problems among older adults presenting to the emergency department. Academic Emergency Medicine, 21(6), 651-658. https://doi.org/10.1111/acem.12395

Susiana, S. (2020). Kekerasan Dalam Rumah Tangga Pada Masa Pandemi Covid-19. Pusat Penelitian Badan Keahlian DPR RI, XII(24).

Trihastuti, A., \& Nuqul, F. L. (2020). Menelaah Pengambilan Keputusan Korban Pelecehan Seksual dalam Melaporkan Kasus Pelecehan Seksual. Personifikasi: Jurnal Ilmu Psikologi, 11(1), 1-15. https://doi.org/10.21107/personifikasi.v1 $1 \mathrm{i} 1.7299$ 
Udousoro, I. (2020). Effective Requirement Engineering Process Model in Software Engineering. Isonkobong Udousoro. Effective Requirement Engineering Process Model in Software Engineering. Software Engineering, $8(1)$, 1-5. https://doi.org/10.11648/j.se.20200801.1 1

Wati, E. F., \& Kusumo, A. A. (2016). Penerapan Metode Unified Modeling Language ( UML) Berbasis Desktop Pada Sistem Pengolahan Kas Kecil Studi Kasus Pada PT Indo Mada Yasa Tangerang. 5(1), 24-36. 